\title{
Comparison of Response of Canola (Brassica napus L. cv Hyola 401) to Biofertilizer Inoculation in Optimal and Delayed Cropping Dates
}

\author{
Esmaeil Yasari ${ }^{1}$ \\ ${ }^{1}$ Department of Agricultural Sciences, Payame Noor University, Iran \\ Correspondence: Esmaeil Yasari, Department of Agricultural Sciences, Payame Noor University, Iran. E-mail: \\ e_yassari@yahoo.com
}

Received: June 11, 2017

Accepted: July 26, 2017 Online Published: August 15, 2017

doi:10.5539/jas.v9n9p192

URL: https://doi.org/10.5539/jas.v9n9p192

\begin{abstract}
In order to compare the effects of phosphate solubilizing bacteria as biofertilizer and mineral phosphorous application in optimal date of sowing with delayed cropping date on canola (Brassica napus L.) growth and productivity, a split-plot experiment using randomized complete block design with three replications was conducted at Dasht-e-Naz Agronomy Research Station in 2014. Four levels of bacterial inoculation (Pseudomonas putida, Pseudomonas fluorescens, singly or in combination) were applied as main plots and five levels of mineral phosphorous application $(0,25,50,75$, and $100 \mathrm{~kg} / \mathrm{ha}$ of mineral phosphorous) were applied as sub plots. Canola plant were sown at two dates of sowing, one at optimal date of sowing (Sept. 30, 2014) and the other one month later as delayed cropping (Oct. 30, 2014). The results obtained showed that effects of bacterial inoculation on number of seeds per pod, number of pods on plant, and seed yield were significant at one percent probability level at both sowing dates. Moreover, rates of phosphate application had significant effects on all traits at one percent level. Comparing the means showed that application of mineral P resulted in substantial increase in seed yield. At optimal date of sowing, it was shown that while minimum seed yield obtained at control treatment $(1600 \mathrm{~kg} / \mathrm{ha})$, the maximum $(2980 \mathrm{~kg} / \mathrm{ha})$ obtained with interaction effects of application of both bacterial strains along with $75 \mathrm{~kg} / \mathrm{ha}$ mineral $\mathrm{P}$, having no statistically difference with that of $P$. fluorescence along with $75 \mathrm{~kg} / \mathrm{ha}$ mineral $\mathrm{P}(2940 \mathrm{~kg} / \mathrm{ha})$. It was shown that delayed cropping resulted in decreasing canola growth which is reflected in seed yield and yield components. Minimum seed yield at control plot at first date of sowing $(1600 \mathrm{~kg} / \mathrm{ha})$ decreased to $740 \mathrm{~kg} / \mathrm{ha}$ in second date of sowing, showing $54 \%$ decrease. The maximum seed yield also decreased in delayed cropping, from $2980 \mathrm{~kg} / \mathrm{ha}$ at Sept. 30, 2014 as compared to $1074 \mathrm{~kg} / \mathrm{ha}$ at Oct. 30, 2014, showing a 64\% decrease. The results obtained showed that an increase in P level, eventually enhanced the seed yield. This increasing trend continued until a threshold level $(75 \mathrm{~kg} / \mathrm{ha}$ of P), after which seed yield showed a declining fashion.
\end{abstract}

Keywords: canola, date of sowing, Pseudomonas putida, Pseudomonas fluorescens, phosphorous

\section{Introduction}

Choice of fertilizers and provision of conditions for optimum nutrient availability is of paramount importance that influences canola (Brassica napus L.) growth and yield, since canola plant is very efficient at taking up nutrients. Advantages of inoculating plants with growth stimulating bacteria include enhancing numerous indicators such as germination rate, root growth, yield per unit area, biological control of pathogens, leaf area, chlorophyll content, drought resistance, weight of aerial parts and roots, and microbial activities (Lucy et al., 2004). Using a judicious combination of chemical fertilizers as well as biofertilizers to obtain the best results can be strategic step. Reports are available on the use of biofertilizers in many crop plants in increasing crop yield and nutrient uptake. Positive effects of inoculation with Azotobacter and Azosperillum on canola (Yasari et al., 2008), wheat and mustard (P. Gupta \& V. Gupta, 2006), mustard (Sharma et al., 1997) have already been reported. Yasari and Rafati Alashti (2013) observed that seed inoculation with Pseudomonas fluorescens and putida resulted in increased soybean seed yield compared to control. They reported that seed yield reached its maximum level when simultaneously was inoculated with both bacterial species. This maximum seed yield was accompanied by the maximum number of pods on the main stem, the highest number of pods per plant, and the largest 1000-seed weight. Under interaction effects of cultivar, phosphorous application, and bacterial inoculation, the maximum seed yield was obtained when seeds of the cultivar Telar were inoculated with P. putida and $50 \mathrm{~kg} / \mathrm{ha}$ 
of phosphorous were applied to the soil. Likewise Gleddie et al. (1993) reported that Penicillium bilaji increased the vegetative growth, $\mathrm{P}$ uptake, and grain yield of canola both with or without $\mathrm{P}$ fertilizer under $\mathrm{P}$ responsive conditions, most likely by solubilizing unavailable soil P. Almas and Saghir (2005) observed that phosphorous content increased considerably in the presence of Pseudomonas striata and Azotobacter in wheat seed. Attention has seldom been given to the nutrient requirement of the soil especially at optimum sowing dates and comparing this with delayed cropping, canola crops have suffered in most cases, either from lack or excess of these nutrients. Hence, the necessity to evaluate the best nutrient uptake for improving canola seed yield, quality and fortification in Mazandaran crops, based on soil test results. The present research study compared canola (Brassica napus L. cv Hyola 401) response to biofertilizer application inoculation in optimal and delayed cropping dates Dasht-e Naz in Sari.

\section{Materials and Methods}

In order to compare canola (Brassica napus L. cv Hyola 401) response to biofertilizer application inoculation in optimal and delayed cropping dates an experiment was conducted at Dasht-e-Naz Agronomy Research Station, Mazandaran, Iran in the cropping year 2014-2015. Canola plant have been sown at two dates of sowing, one at optimal date of sowing (Sept. 30, 2014) and the other one month later as delayed cropping (Oct. 30, 2014). The experimental site has an altitude of $13.5 \mathrm{~m}$, longitude of $53^{\circ} 11^{\prime}$ and latitude of $36^{\circ} 04^{\prime}$. The average annual rainfall at the station was $685 \mathrm{~mm}$, and it has a temperate Caspian climate and maximum and minimum annual temperatures of $27.3{ }^{\circ} \mathrm{C}$ and $7.1{ }^{\circ} \mathrm{C}$. The experiment was carried out in the split plot arrangement using the randomized complete block design with three replications. Four levels of bacteria (the control, Pseudomonas putida, Pseudomonas fluorescens, and simultaneous use of both bacterial species) were the treatments in the main plots, and five levels of mineral phosphorous application (the control, 25, 50, 75, and $100 \mathrm{~kg} / \mathrm{ha}$ of phosphorous in the form of concentrated superphosphate) the treatments in the sub plots. A composite sample of soil from the surface of the ground down to the depth of $30 \mathrm{~cm}$ was taken and sent to a laboratory for determining the physical and chemical features of the soil and for measuring the content of plant nutrients (especially that of phosphorous). Results of tests carried out on these samples showed that the organic matter, the available phosphorous, and the available potassium contents of the soil were $2.51 \%, 6.7 \mathrm{ppm}$, and $297 \mathrm{ppm}$, respectively. The soil $\mathrm{pH}$ was 7.7 with loamy clay texture containing $37 \%$ clay, $26 \%$ silt, and $37 \%$ sand. Each experimental plot included five $5-\mathrm{m}$ lines $30 \mathrm{~cm}$ apart. The distance between adjacent plots was 1 meter and between replications 2 meters (used as passage way). Harvest was carried out at full physiological maturity and yield was measured at 14 percent moisture content. At crop maturity, ten plants were randomly selected from each plot and their seed yield and yield components (including number of seed per pod, number of pod in main stem and per plant, the length of pod, and the 1000-seed weight) were measured. Analysis of the variance was performed using the SAS statistical software, and comparison of the means of the data was performed on the basis of Duncan's multiple range test at the five percent probability level.

\section{Results and Discussion}

\subsection{Number of Lateral Shoots}

The results of analysis of variation showed that at first date of sowing (Sept. 30) only level of bacterial inoculation was significant on number of lateral shoots at $1 \%$ level (Table 1). The results obtained showed that number of lateral shoots increased with application of either treatments mineral $\mathrm{P}$ or phosphate solubilizing bacteria (PSB) in both sowing dates. At optimal date of sowing (first date), minimum number of lateral shoots (3.40) obtained at control treatments (neither application of mineral $\mathrm{P}$ nor bacterial inoculation) and the maximum number (4.46) at interaction effects of both bacterial species along with 25 or $75 \mathrm{~kg} / \mathrm{ha}$ mineral $\mathrm{P}$ (Table 3). Analysis of variation at second date of sowing (Oct. 30) also showed that main effects of rates of mineral P and level of bacterial inoculation were significant on number of lateral shoots at $1 \%$ level (Table 2). At delayed cropping the minimum number of lateral shoots (2.38) obtained at control treatments and the maximum number (3.99) at interaction effects of both bacterial species along with $75 \mathrm{~kg} / \mathrm{ha}$ mineral P (Table 2). Dehpouri et al. (2015) reported that maximum number of lateral shoots (3.23) was observed in the treatment of applying $75 \mathrm{~kg} / \mathrm{ha}$ of phosphorous, but this number was not significantly different from those obtained by applying phosphorous at 25 or $50 \mathrm{~kg} / \mathrm{ha}$. They also observed that maximum number of lateral shoots was obtained at the simultaneous application of both the bacterial strains P. putida and P. fluorescens in canola plants. The results of present study were in agreement with those observed by Dehpouri et al. (2015) and Freitas et al. (1997). 
Table 1. Analysis of variation of the data related to the studied traits at the first date of sowing

\begin{tabular}{llllllll}
\hline & & \multicolumn{5}{c}{ Mean Squares } \\
\cline { 3 - 7 } Sources of Variation & $\begin{array}{l}\text { Degree of } \\
\text { Freedom }\end{array}$ & $\begin{array}{l}\text { Number of } \\
\text { lateral shoots }\end{array}$ & $\begin{array}{l}\text { Number of } \\
\text { pods on the } \\
\text { main stem }\end{array}$ & $\begin{array}{l}\text { Number of } \\
\text { pods per } \\
\text { plant }\end{array}$ & $\begin{array}{l}\text { Length } \\
\text { of pods }\end{array}$ & $\begin{array}{l}\text { Number of } \\
\text { seeds per pod }\end{array}$ & Seed yield \\
\hline Replication & 2 & 0.002 & 75.266 & 951.122 & 1.604 & $92.266^{* *}$ & $1481.867 \mathrm{~ns}$ \\
Rate of phosphate & 3 & $0.487^{\text {ns }}$ & $216.886^{*}$ & $537.878^{*}$ & 0.155 & $45.439^{*}$ & $54840.283^{* *}$ \\
Error & 6 & 0.302 & 34.560 & 391.629 & 0.411 & 8.757 & 1572.133 \\
Level of bacterial inoculation & 4 & $1.161^{* *}$ & $138.526^{* *}$ & $2528.918^{* *}$ & $0.792^{* *}$ & $74.423^{* *}$ & $96978.942^{* *}$ \\
Interaction effects & 12 & $0.063^{\text {ns }}$ & $0.063^{\text {ns }}$ & $123.512^{\text {ns }}$ & $0.691^{\text {ns }}$ & $4.962^{\text {ns }}$ & $1748.908^{*}$ \\
Error & 32 & 0.052 & 0.052 & 152.103 & 1.630 & 5.072 & 9065.379 \\
\hline Coefficient of variation $(\%)$ & - & 5.64 & 5.64 & 6.87 & 5.01 & 7.58 & 10.16 \\
\hline Note.
\end{tabular}

Note. ns, ${ }^{*}, * *$ refer to non significant, significant at five and one percent probability levels, respectively.

Table 2. Analysis of variation of the data related to the studied traits at the second date of sowing

\begin{tabular}{llllllll}
\hline & & \multicolumn{5}{c}{ Mean Squares } \\
\cline { 3 - 8 } Source of Variation & $\begin{array}{l}\text { Degree of } \\
\text { freedom }\end{array}$ & $\begin{array}{l}\text { No. of } \\
\text { lateral } \\
\text { shoots }\end{array}$ & $\begin{array}{l}\text { No. of pods } \\
\text { on the main } \\
\text { stem }\end{array}$ & $\begin{array}{l}\text { No. of pods } \\
\text { per plant }\end{array}$ & $\begin{array}{l}\text { Pod length } \\
(\mathrm{cm})\end{array}$ & $\begin{array}{l}\text { No. of seeds } \\
\text { per pod }\end{array}$ & $\begin{array}{l}\text { Seed yield } \\
(\mathrm{kg} / \mathrm{ha})\end{array}$ \\
\hline Replication & 2 & $0.184 \mathrm{~ns}$ & $42.187 \mathrm{~ns}$ & $677.262 \mathrm{~ns}$ & $0.594 \mathrm{~ns}$ & $45.210^{*}$ & $2020.07 \mathrm{~ns}$ \\
Rate of phosphate & 3 & $2.654^{* *}$ & $213.567^{*}$ & $521.278 \mathrm{~ns}$ & $0.500 \mathrm{~ns}$ & $22.265^{*}$ & $5481.12^{* *}$ \\
Error & 6 & 0.137 & 24.407 & 185.304 & $0.796 \mathrm{~ns}$ & 4.291 & 1325.45 \\
Level of bacterial inoculation & 4 & $0.599^{* *}$ & $101.666^{* *}$ & $1169.833^{* *}$ & $1.752^{* *}$ & $36.467^{* *}$ & $869.112^{* *}$ \\
Interaction effects & 12 & $0.035 \mathrm{~ns}$ & $18.089^{*}$ & $39.811 \mathrm{~ns}$ & $0.084 \mathrm{~ns}$ & $2.431 \mathrm{~ns}$ & 456.11 \\
Error & 32 & 0.45 & 6.605 & 61.907 & 0.317 & 2.485 & 9065.379 \\
\hline Coefficient of variation & - & 7.03 & 4.48 & 6.22 & 14.61 & 7.58 & 10.16 \\
\hline
\end{tabular}

Note. ${ }^{*},{ }^{*}$, ns represent significant at $5 \%, 1 \%$, and not significant, respectively.

Table 3. Comparison of the means of the individual and interaction effects of phosphate and inoculation levels on No. of lateral shoots

\begin{tabular}{|c|c|c|c|c|c|c|}
\hline \multicolumn{2}{|l|}{ Phosphate rate $(\mathrm{kg} / \mathrm{ha})$} & \multirow{2}{*}{$\begin{array}{l}\begin{array}{l}\text { Control } \\
\text { (no inoculation) }\end{array} \\
3.4 \mathrm{c}\end{array}$} & \multirow{2}{*}{$\begin{array}{l}\text { P. putida } \\
3.46 \mathrm{c}\end{array}$} & \multirow{2}{*}{$\begin{array}{l}\text { P. fluorescens } \\
3.46 \mathrm{c}\end{array}$} & \multirow{2}{*}{$\begin{array}{l}\text { Inoculation with } \\
\text { both species }\end{array}$} & \multirow{2}{*}{$\begin{array}{l}\begin{array}{l}\text { Average of } \\
\text { Phosphate rate }\end{array} \\
3.50\end{array}$} \\
\hline First date of sowing (Sept. 30) & 0 & & & & & \\
\hline & 25 & $3.8 \mathrm{c}$ & $4.20 \mathrm{bc}$ & $4.40 \mathrm{ab}$ & $4.46 \mathrm{a}$ & 4.21 \\
\hline & 50 & $3.86 \mathrm{c}$ & $4.06 \mathrm{bc}$ & $4.46 \mathrm{a}$ & $4.33 \mathrm{ab}$ & 4.18 \\
\hline & 75 & $4.23 \mathrm{bc}$ & $4.20 \mathrm{abc}$ & $4.33 \mathrm{ab}$ & $4.20 \mathrm{abc}$ & 4.24 \\
\hline & 100 & $3.86 \mathrm{c}$ & $4.06 \mathrm{bc}$ & $4.20 \mathrm{abc}$ & $4.46 \mathrm{a}$ & 4.15 \\
\hline \multicolumn{2}{|l|}{ Average of bacterial inoculation } & 3.83 & 4 & 4.17 & 4.23 & \\
\hline \multirow[t]{5}{*}{ Second date of sowing (Oct. 30) } & 0 & $2.38 \mathrm{~h}$ & $2.42 \mathrm{~h}$ & $2.42 \mathrm{~h}$ & $3.32 \mathrm{bcd}$ & 2.63 \\
\hline & 25 & $2.66 \mathrm{~g}$ & 2.94 defg & $3.08 \mathrm{cdef}$ & $3.69 \mathrm{ab}$ & 3.09 \\
\hline & 50 & $2.70 \mathrm{fgh}$ & $2.84 \mathrm{efg}$ & $3.12 \mathrm{cde}$ & $3.63 \mathrm{ab}$ & 3.07 \\
\hline & 75 & $2.96 \mathrm{defg}$ & $2.94 \mathrm{defg}$ & 3.03 defg & $3.99 \mathrm{a}$ & 3.23 \\
\hline & 100 & $2.70 \mathrm{fgh}$ & $2.84 \mathrm{efg}$ & $3.94 \mathrm{a}$ & $2.46 \mathrm{bc}$ & 2.98 \\
\hline \multicolumn{2}{|l|}{ Average of bacterial inoculation } & 2.68 & 2.79 & 3.11 & 3.41 & \\
\hline
\end{tabular}

Note. Values within a column followed by same letter are not significantly different at Duncan $(\mathrm{p} \leq 0.05)$.

\subsection{Number of Pods on the Main Stem}

Comparison of the means revealed that number of pods on main stem increased with application of mineral $\mathrm{P}$ and bacterial inoculation. In both factors minimum number of pods on the main stem obtained at control 
treatments whereas the maximum number obtained at higher level of application of mineral $\mathrm{P}$ or bacterial inoculation (Table 4). Numbers of pods are the most important yield components affecting seed yield, which is already described by several researchers (Shukla et al., 2002; Khalid et al, 2004; Yasari et al., 2009). Comparing the means of the interaction effects of phosphate application and inoculation at first date of sowing showed that minimum number of pods on the main stem (71.86) was at control plot, and the maximum (87.53) at the treatment in which seeds were inoculated with both bacterial along with $25 \mathrm{~kg} / \mathrm{ha}$ of mineral P application (Table 4). At the second date of sowing however, the minimum number of pods on the main stem (50.31) was at control and the maximum (66.77) belonged to the treatment in which both bacterial species were applied along with 50 $\mathrm{kg} / \mathrm{ha}$ of mineral phosphorous. The results of the present investigation was fairly comparable with those obtained by Saber et al. (2013) who suggested an increased number of pods in canola plant by PGPR.

Table 4. Comparison of the means of the individual and interaction effects of phosphate and inoculation levels on number of pods on the main stem

\begin{tabular}{|c|c|c|c|c|c|c|}
\hline Phosphate rate $(\mathrm{kg} / \mathrm{ha})$ & on level & $\begin{array}{l}\text { Control } \\
\text { (no inoculation) }\end{array}$ & P. putida & P. fluorescens & $\begin{array}{l}\text { Inoculation with } \\
\text { both species }\end{array}$ & $\begin{array}{l}\text { Average of } \\
\text { Phosphate rate }\end{array}$ \\
\hline \multirow[t]{5}{*}{ First date of sowing (Sept. 30) } & 0 & $71.86 \mathrm{f}$ & 74.80 ef & $78.67 \mathrm{cde}$ & 74.80 ef & 74.88 \\
\hline & 25 & $79.20 \mathrm{cde}$ & $77.53 \mathrm{de}$ & $83.86 \mathrm{abc}$ & $87.53 \mathrm{a}$ & 82.03 \\
\hline & 50 & 74.66 ef & $77.26 \mathrm{de}$ & $87.13 \mathrm{ab}$ & $85.86 \mathrm{ab}$ & 81.23 \\
\hline & 75 & $82.80 \mathrm{bc}$ & $77.33 \mathrm{de}$ & $85.66 \mathrm{ab}$ & $86.06 \mathrm{ab}$ & 82.96 \\
\hline & 100 & $79.73 \mathrm{~cd}$ & $80.33 \mathrm{~cd}$ & $86.60 \mathrm{ab}$ & $83.26 \mathrm{abc}$ & 82.98 \\
\hline \multicolumn{2}{|l|}{ Average of bacterial inoculation } & 77.65 & 77.45 & 84.66 & 83.50 & \\
\hline \multirow[t]{5}{*}{ Second date of sowing (Oct. 30) } & 0 & $50.31 \mathrm{~h}$ & $52.36 \mathrm{gh}$ & $54.46 \mathrm{fgh}$ & $52.36 \mathrm{gh}$ & 52.37 \\
\hline & 25 & $55.44 \mathrm{efg}$ & $54.27 \mathrm{fgh}$ & 58.71 cdef & $61.27 \mathrm{bcd}$ & 57.42 \\
\hline & 50 & $52.27 \mathrm{gh}$ & $54.09 \mathrm{fgh}$ & $60.99 \mathrm{bcd}$ & $66.77 \mathrm{a}$ & 58.53 \\
\hline & 75 & $57.96 \mathrm{def}$ & $54.13 \mathrm{fgh}$ & 59.97 cde & $65.58 \mathrm{ab}$ & 59.41 \\
\hline & 100 & $55.81 \mathrm{efg}$ & $56.23 \mathrm{efg}$ & $62.02 \mathrm{bcd}$ & $63.29 \mathrm{abc}$ & 59.33 \\
\hline \multicolumn{2}{|l|}{ Average of bacterial inoculation } & 51.35 & 54.21 & 59.23 & 61.85 & \\
\hline
\end{tabular}

Note. Values within a column followed by same letter are not significantly different at Duncan $(\mathrm{p} \leq 0.05)$.

\subsection{Number of Pods per Plant}

The number of pods per plant increased with application of mineral $\mathrm{P}$ as well as PSB. The maximum number obtained at the treatment of higher levels of $\mathrm{P}$ application either mineral or bacterial (Table 5). Comparing the means of the interaction effects of phosphate application and inoculation at first date of sowing showed that the minimum number of pods in plant (151.06) was at control plot, and the maximum (213.4) at the treatment in which seeds were inoculated with $P$. fluorescens at present of $75 \mathrm{~kg} / \mathrm{ha}$ of mineral P application (Table 5). At the second date of sowing however, the minimum number of pods on plant (105.7) was at control and the maximum (149.4) belonged to the treatment in which P. fluorescens was applied along with $75 \mathrm{~kg} / \mathrm{ha}$ of mineral $\mathrm{P}$. These observations were in conformity with those observed Saber et al. (2013) and Freitas et al. (1997) in their study on effects of PGPR and PSB on canola, respectively. 
Table 5. Comparison of the means of the individual and interaction effects of phosphate and inoculation levels on the number of pods per plant

\begin{tabular}{|c|c|c|c|c|c|c|}
\hline \multicolumn{2}{|l|}{ Phosphate rate $(\mathrm{kg} / \mathrm{ha})$} & \multirow{2}{*}{$\begin{array}{l}\text { Control } \\
\text { (no inoculation) }\end{array}$} & \multirow{2}{*}{$\begin{array}{l}\text { P. putida } \\
152.86 \mathrm{e}\end{array}$} & \multirow{2}{*}{$\begin{array}{l}\text { P. fluorescens } \\
159.60 \mathrm{de}\end{array}$} & \multirow{2}{*}{$\begin{array}{l}\text { Inoculation with } \\
\text { both species } \\
157.20 \mathrm{e}\end{array}$} & \multirow{2}{*}{$\begin{array}{l}\begin{array}{l}\text { Average of } \\
\text { Phosphate rate }\end{array} \\
155.18\end{array}$} \\
\hline First date of sowing (Sept. 30) & 0 & & & & & \\
\hline & 25 & $177.40 \mathrm{bcd}$ & 175.93 bcde & $184.86 \mathrm{~b}$ & 175.93 bcde & 178.53 \\
\hline & 50 & $184.80 \mathrm{~b}$ & $190.86 \mathrm{ab}$ & $194.93 \mathrm{ab}$ & $188.53 \mathrm{~b}$ & 189.78 \\
\hline & 75 & $180.53 \mathrm{~b}$ & $176.20 \mathrm{bcd}$ & $213.40 \mathrm{a}$ & $194.80 \mathrm{ab}$ & 191.23 \\
\hline & 100 & $179.73 \mathrm{bc}$ & $179.67 \mathrm{bc}$ & $184.53 \mathrm{bc}$ & $185.53 \mathrm{~b}$ & 182.21 \\
\hline Average of bacterial inoculation & & 174.70 & 174.98 & 187.46 & 180.40 & \\
\hline \multirow[t]{5}{*}{ Second date of sowing (Oct. 30) } & 0 & $105.7 \mathrm{f}$ & $107.0 \mathrm{f}$ & $116.7 \mathrm{def}$ & 110.0 ef & 109.85 \\
\hline & 25 & $124.2 \mathrm{cde}$ & 123.2 cde & $132.7 \mathrm{bc}$ & $123.2 \mathrm{cde}$ & 125.82 \\
\hline & 50 & $129.4 \mathrm{bcd}$ & $133.6 \mathrm{bc}$ & $139.8 \mathrm{ab}$ & $132.0 \mathrm{bcd}$ & 133.7 \\
\hline & 75 & $126.4 \mathrm{bcd}$ & $123.3 \mathrm{cde}$ & $149.4 \mathrm{a}$ & $136.4 \mathrm{abc}$ & 133.87 \\
\hline & 100 & $125.8 \mathrm{bcd}$ & $125.3 \mathrm{bcd}$ & $135.8 \mathrm{abc}$ & $129.9 \mathrm{bcd}$ & 129.2 \\
\hline Average of bacterial inoculation & & 122.3 & 122.48 & 134.88 & 126.3 & \\
\hline
\end{tabular}

Note. Values within a column followed by same letter are not significantly different at Duncan $(\mathrm{p} \leq 0.05)$.

\subsection{Pod Length}

The results obtained showed that pod length also was affected with application of mineral P as well as PSB. The minimum pod length obtained at control treatment at both dates of sowing (Table 6). Comparing the means of the interaction effects of phosphate application and inoculation at first date of sowing showed the minimum pods length $(3.87 \mathrm{~mm})$ with $P$. putida and no mineral $\mathrm{P}$ application. The maximum pods length $(4.89 \mathrm{~mm})$ at the treatment in which seeds were inoculated with both species inoculation along with $75 \mathrm{~kg} / \mathrm{ha}$ of mineral P (Table 6). At the second date of sowing it was shown that the minimum pods length $(3.07 \mathrm{~mm})$ was at control and the maximum (4.45 and $4.47 \mathrm{~mm}$ ) belonged to P. fluorescens with 75 and $50 \mathrm{~kg} / \mathrm{ha}$ of mineral P. Similar observations have already been seen by Saber et al. (2013) and Freitas et al. (1997) in their study on effects of PGPR and PSB on canola, respectively.

Table 6. Comparison of the means of the individual and interaction effects of phosphate and inoculation levels on pod length

\begin{tabular}{|c|c|c|c|c|c|c|}
\hline \multicolumn{2}{|l|}{ Phosphate rate $(\mathrm{kg} / \mathrm{ha})$} & \multirow{2}{*}{$\begin{array}{l}\text { Control } \\
\text { (no inoculation) }\end{array}$} & \multirow{2}{*}{$\begin{array}{l}\text { P. putida } \\
3.87 \mathrm{~d}\end{array}$} & \multirow{2}{*}{$\begin{array}{l}\text { P. fluorescens } \\
4.31 \mathrm{abcd}\end{array}$} & \multirow{2}{*}{$\begin{array}{l}\text { Inoculation with } \\
\text { both species } \\
4.11 \mathrm{~cd}\end{array}$} & \multirow{2}{*}{$\begin{array}{l}\text { Average of } \\
\text { Phosphate rate }\end{array}$} \\
\hline First date of sowing (Sept. 30) & 0 & & & & & \\
\hline & 25 & $4.24 \mathrm{bcd}$ & $4.55 \mathrm{abc}$ & $4.62 \mathrm{abc}$ & $4.75 \mathrm{ab}$ & 4.54 \\
\hline & 50 & $4.60 \mathrm{abc}$ & $4.51 \mathrm{abc}$ & $4.75 \mathrm{ab}$ & $4.59 \mathrm{abc}$ & 4.61 \\
\hline & 75 & $4.66 \mathrm{abc}$ & $4.56 \mathrm{abc}$ & $4.64 \mathrm{abc}$ & $4.89 \mathrm{a}$ & 4.69 \\
\hline & 100 & $4.71 \mathrm{ab}$ & $4.54 \mathrm{abc}$ & $4.51 \mathrm{abc}$ & $4.68 \mathrm{abc}$ & 4.61 \\
\hline \multicolumn{2}{|l|}{ Average of bacterial inoculation } & 4.42 & 4.41 & 4.57 & 4.61 & \\
\hline \multirow[t]{5}{*}{ Second date of sowing (Oct. 30) } & 0 & $3.07 \mathrm{~d}$ & $3.38 \mathrm{bcd}$ & 3.68 abcd & $3.21 \mathrm{~cd}$ & 3.33 \\
\hline & 25 & $3.63 \mathrm{abcd}$ & $3.72 \mathrm{abcd}$ & 3.88 abcd & 3.99 abcd & 3.81 \\
\hline & 50 & $4.25 \mathrm{abc}$ & $4.56 \mathrm{a}$ & $4.47 \mathrm{ab}$ & $4.31 \mathrm{abcd}$ & 4.40 \\
\hline & 75 & $3.76 \mathrm{abcd}$ & $3.62 \mathrm{abcd}$ & $4.45 \mathrm{ab}$ & $3.96 \mathrm{abcd}$ & 3.95 \\
\hline & 100 & $3.63 \mathrm{abcd}$ & $3.68 \mathrm{abcd}$ & $4.02 \mathrm{abcd}$ & $3.74 \mathrm{abcd}$ & 3.77 \\
\hline \multicolumn{2}{|l|}{ Average of bacterial inoculation } & 3.67 & 3.79 & 4.10 & 3.84 & \\
\hline
\end{tabular}

Note. Values within a column followed by same letter are not significantly different at Duncan $(\mathrm{p} \leq 0.05)$. 


\subsection{Number of Seeds per Pod}

The results obtained showed that mineral $\mathrm{P}$ or bacterial inoculation increased the number of seeds per pod in both dates of sowing. The minimum number of seeds per pod obtained at control plots (25.18) and the maximum number (35.8) at the conjunctive application of $75 \mathrm{~kg} / \mathrm{ha}$ mineral $\mathrm{P}$ and both bacteria strains at the first date of sowing (Table 7). Comparing the means of the interaction effects of inoculation and phosphate application at second date of sowing revealed that the maximum number of seeds per pod (25.06) was observed in the treatment of simultaneous inoculation with P. putida and P. fluorescens and application of phosphate at $75 \mathrm{~kg} / \mathrm{ha}$, and the minimum (17.45) in the treatment of inoculation with P. putida with no phosphate application. Numbers of seeds per pod are also considered to be important yield components affecting seed yield (Shukla et al., 2002; Khalid et al., 2004; Yasari et al., 2009). Similar observations were already made by Saber et al. (2013) in their investigation on effects of PGPR on rapeseed.

Table 7. Comparison of the means of the individual and interaction effects of phosphate and inoculation levels on number of seeds per pod

\begin{tabular}{|c|c|c|c|c|c|c|}
\hline Phosphate rate $(\mathrm{kg} / \mathrm{ha})$ & tion level & $\begin{array}{l}\text { Control } \\
\text { (no inoculation) }\end{array}$ & P. putida & P. fluorescens & $\begin{array}{l}\text { Inoculation with } \\
\text { both species }\end{array}$ & $\begin{array}{l}\text { Average of } \\
\text { Phosphate rate }\end{array}$ \\
\hline \multirow[t]{5}{*}{ First date of sowing (Sept. 30) } & 0 & $25.18 \mathrm{c}$ & $24.92 \mathrm{c}$ & $26.55 \mathrm{bc}$ & $25.41 \mathrm{c}$ & 25.51 \\
\hline & 25 & $29.59 \mathrm{abc}$ & $27.80 \mathrm{bc}$ & $28.30 \mathrm{bc}$ & $32.30 \mathrm{ab}$ & 24.98 \\
\hline & 50 & $30.30 \mathrm{abc}$ & $28.35 \mathrm{bc}$ & $29.16 \mathrm{abc}$ & $35.04 \mathrm{ab}$ & 30.71 \\
\hline & 75 & $30.66 \mathrm{abc}$ & $30.68 \mathrm{abc}$ & $30.66 \mathrm{abc}$ & $35.80 \mathrm{a}$ & 31.95 \\
\hline & 100 & $30.64 \mathrm{abc}$ & $29.44 \mathrm{abc}$ & $30.50 \mathrm{abc}$ & $32.54 \mathrm{ab}$ & 30.78 \\
\hline \multicolumn{2}{|l|}{ Average of bacterial inoculation } & 29.27 & 28.24 & 29.03 & 32.21 & \\
\hline \multirow[t]{5}{*}{ Second date of sowing (Oct. 30) } & 0 & 17.63 ef & $17.45 \mathrm{ab}$ & $18.59 \mathrm{cdef}$ & $17.79 \mathrm{def}$ & 17.86 \\
\hline & 25 & $20.72 \mathrm{bcd}$ & $19.46 \mathrm{f}$ & 19.81 bcdef & $22.61 \mathrm{ab}$ & 20.65 \\
\hline & 50 & $21.21 \mathrm{bc}$ & $19.85 \mathrm{cdef}$ & 20.42 bcdef & $24.53 \mathrm{a}$ & 21.50 \\
\hline & 75 & $21.47 \mathrm{bc}$ & 21.48 bcdef & $21.46 \mathrm{bc}$ & $25.06 \mathrm{a}$ & 22.36 \\
\hline & 100 & $21.45 \mathrm{bc}$ & 20.61 bcde & $21.35 \mathrm{bc}$ & $22.78 \mathrm{ab}$ & 21.59 \\
\hline \multicolumn{2}{|l|}{ Average of bacterial inoculation } & 20.49 & 19.77 & 20.32 & 22.55 & \\
\hline
\end{tabular}

Note. Values within a column followed by same letter are not significantly different at Duncan $(\mathrm{p} \leq 0.05)$.

\subsection{Seed Yield}

The results of analysis of variation showed that at first date of sowing (Sept. 30, 2014) the individual effects of inoculation and its interaction effects with phosphate application on seed yield at the 5\% probability level and of phosphate application rates at the $1 \%$ probability level were significant at both dates of sowing (Table 1). Comparing the means showed that application of mineral P resulted in substantial increase in seed yield. It was shown that while minimum seed yield obtained at control treatment $(1600 \mathrm{~kg} / \mathrm{ha})$, maximum seed yield (2980 $\mathrm{kg} / \mathrm{ha}$ ) obtained at interaction effects of application of both bacterial strains along with 75 mineral $\mathrm{P}$, having no statistically difference with that of $P$. fluorescence along with 75 mineral P $(2940 \mathrm{~kg} / \mathrm{ha})$ (Table 8). The results obtained showed that an increase in P level, eventually enhanced the seed yield. This increasing trend continued until a threshold level $(75 \mathrm{~kg} / \mathrm{ha}$ of P), after which seed yield showed a declining fashion. Similar observations have been made by Baradari et al. (2013) in their examination on canola; Yasari and Rafati Alashti (2013) in their investigation on soybean and Ebrahimi Chamani et al. (2014) in their experiment on rice. It was also observed that applying higher rates of phosphorous together with inoculating seeds with bacteria resulted in lower seed yields. This could signify the antagonistic effects of bacterial inoculation with higher rates of phosphorous application. At the second date of sowing (Oct. 30, 2014) however, results of analysis of variation showed that the individual effects of inoculation and its interaction effects with phosphate application on seed yield at the $5 \%$ probability level and of phosphate application rates at the $1 \%$ probability level were significant at both dates of sowing (Table 2). Comparison of the means related to the interaction effects of phosphorous and bacteria indicated the maximum seed yield $(1074 \mathrm{~kg} / \mathrm{ha})$ was achieved in the treatment in which both P. putida and $P$. fluorescens were simultaneously used and phosphorous was applied at $50 \mathrm{~kg} / \mathrm{ha}$. This yield was not significantly different from the $1073 \mathrm{~kg} / \mathrm{ha}$ obtained in the treatment of applying phosphorous at $50 \mathrm{~kg} / \mathrm{ha}$ of phosphorous and using $P$. fluorescens. The lowest seed yield $(740 \mathrm{~kg} / \mathrm{ha})$ was that of the treatment in which 
phosphorous was not applied and neither was inoculation performed. This yield was not significantly different from the $740 \mathrm{~kg} / \mathrm{ha}$ obtained when no inoculation was performed but phosphorous was applied at $100 \mathrm{~kg} / \mathrm{ha}$ (Table 8). It was shown that delayed cropping resulted in decreasing canola growth which is reflected in seed yield and yield components. Minimum seed yield at control plot at first date of sowing $(1600 \mathrm{~kg} / \mathrm{ha})$ decreased (to $740 \mathrm{~kg} / \mathrm{ha}$ ) in second date of sowing, showing 54\% decrease. The maximum seed yield also decreased in delayed cropping, from $2980 \mathrm{~kg} / \mathrm{ha}$ at Sept. 302014 to $1074 \mathrm{~kg} / \mathrm{ha}$ at Oct. 30, 2014, showing a 64\% decrease. Besides making mineral soil elements available to plants, phosphate solubilizing bacteria act as nitrogen fixing agents, solubilize phosphorous and potassium, suppress pathogens, and increase yield through producing plant growth regulators (Sturz \& Christie, 2003). Researchers found that adding Pseudomonas fluorescens increased yield of various crop plants. These results are in agreement with those obtained by Yasari and Rafati Alashti (2013) in their research work on soybean crop. They reported that the pseudomonas species activity declined at the higher levels of mineral $\mathrm{P}$ availability, pointing the antagonistic effects of bacterial activity in higher levels of phosphorous availability. Similar observation have also been made by Tran et al. (2006), and Aris, Rika, and Giyanto (2011) in their study on effects of Pseudomonas species on soybean plant. Soleimanzadeh and Ghooshchi (2013) reported that high inputs cropping system was the most productive treatment but organic cropping system with biofertilizers was the most economical treatment with respect to increasing net profit in their study on maize. Winarso et al. (2011) found that the simultaneous use of humic acid and strains of the species of $P$. putida increased soil $\mathrm{pH}$ and, hence, raised the availability of phosphorous (and improved other soil features). They also reported that the simultaneous employment of humic acid and strains of $P$. putida increased seed yield. The results of the present study was in conformity with those obtained by Burd et al. (2000) who reported that PGPR might improve plant growth and productivity by synthesizing phytohormones, enhance the general availability of nutrients. It can be therefore concluded that instead of application of higher rates of mineral phosphorous without application of PSB, a combined application of phosphate solubilizing bacteria and optimum levels of mineral $\mathrm{P}$ can be more effective in terms of canola crop healthy growth and optimal productivity. These results definite the previous finding who reported growth and yield in various crop plants by microbial inoculation (Biswas et al., 2000; Fallik \& Okon, 1988; Marcos et al., 1995; Naveed et al., 2008).

Table 8. Comparison of the means of the individual and interaction effects of phosphate and inoculation levels on seed yield

\begin{tabular}{|c|c|c|c|c|c|c|}
\hline \multicolumn{2}{|l|}{ Phosphate rate $(\mathrm{kg} / \mathrm{ha})$} & \multirow{2}{*}{$\begin{array}{l}\text { Control } \\
\text { (no inoculation) }\end{array}$} & \multirow{2}{*}{$\begin{array}{l}\text { P. putida } \\
1480 \mathrm{k}\end{array}$} & \multirow{2}{*}{$\begin{array}{l}\text { P. fluorescens } \\
2030 \mathrm{gh}\end{array}$} & \multirow{2}{*}{$\begin{array}{l}\text { Inoculation with } \\
\text { both species }\end{array}$} & \multirow{2}{*}{$\begin{array}{l}\text { Average of } \\
\text { Phosphate rate } \\
1810\end{array}$} \\
\hline First date of sowing (Sept. 30) & 0 & & & & & \\
\hline & 25 & $2230 \mathrm{i}$ & $2380 \mathrm{fg}$ & $2490 \mathrm{f}$ & 2510 ef & 2402 \\
\hline & 50 & 2150 hi & 2640 cde & $2860 \mathrm{ab}$ & $2790 \mathrm{bcd}$ & 2610 \\
\hline & 75 & 2650 cde & $2790 \mathrm{bcd}$ & $2940 \mathrm{ab}$ & $2980 \mathrm{a}$ & 2840 \\
\hline & 100 & $2490 \mathrm{f}$ & 2630 de & 2730 bcde & $1953 \mathrm{i}$ & 2450 \\
\hline \multicolumn{2}{|l|}{ Average of bacterial inoculation } & 2224 & 2384 & 2610 & 2472 & \\
\hline \multirow[t]{5}{*}{ Second date of sowing (Oct. 30) } & 0 & $740.0 \mathrm{e}$ & $822.0 \mathrm{de}$ & 904.0 abcde & 914.0 abcde & 845 \\
\hline & 25 & 860.0 bcde & $962.0 \mathrm{abcd}$ & $1023.0 \mathrm{abc}$ & $1010.0 \mathrm{abc}$ & 963.75 \\
\hline & 50 & $953.0 \mathrm{abcd}$ & $1026.0 \mathrm{abc}$ & $1073.0 \mathrm{a}$ & $1074.0 \mathrm{a}$ & 1031.5 \\
\hline & 75 & $958.0 \mathrm{abcd}$ & $1004.0 \mathrm{abcd}$ & $1039.0 \mathrm{ab}$ & $1022.0 \mathrm{abc}$ & 1005.75 \\
\hline & 100 & $751.0 \mathrm{e}$ & 867.0 bcde & 900.0 abcde & 840.3 cde & 839.75 \\
\hline \multicolumn{2}{|l|}{ Average of bacterial inoculation } & 852.4 & 936.2 & 987.8 & 972.06 & \\
\hline
\end{tabular}

Note. Values within a column followed by same letter are not significantly different at Duncan $(\mathrm{p} \leq 0.05)$.

\section{Conclusion}

In general it appears that delayed cropping resulted in decreasing canola growth which is reflected in seed yield and yield components. Seed yield at control plot at first date of sowing decreased in second date of sowing, showing 54\% decrease. Application of P. putida and P. fluorescens can be effective in terms of canola growth augmentation. The effects of such biofertilizer reflects on different aspects of canola growth, yield and yield attributing characteristics. It was also shown that simultaneous application of both pseudomonas strains was more effective comparing to their individual application. It was observed that applying maximum level of 
mineral phosphorous together with inoculating seeds with bacteria resulted in lower seed yields. This could signify the antagonistic effects of bacterial inoculation with higher rates of phosphorous application. Therefore it can be recommended that instead of application of exceeding rate of mineral $\mathrm{P}$, which can cause retarding effects on other mineral nutrients especially micronutrients such as $\mathrm{Zn}, \mathrm{Fe}, \mathrm{Mn}$, additional biofertilizers application such as PSB could be more effective and beneficial. In the other word it can postulated that instead of application of exceeding rates of mineral phosphorous without application of PSB, a combined application of phosphate solubilizing bacteria and optimum levels of mineral $\mathrm{P}$ can be more effective in terms of canola crop healthy growth and optimal productivity.

\section{References}

Almas, Z., \& Saghir, K. (2005). Interactive effect of rhizotrophic micro-organisms on growth, yield, and nutrient uptake of wheat. Journal of Plant Nutrition, 28(12), 2079-2092. https://doi.org/10.1080/019041605003 20897

Aris, T. W., Rika, I. A., \& Giyanto, G. (2011). Screening of Pseudomonas sp. Isolated from Rhizosphere of Soybean Plant as Plant Growth Promoter and Bio-control Agent. American Journal of Agricultural and Biological Sciences, 6(1), 134-141. https://doi.org/10.3844/ajabssp.2011.134.141

Baradari, B. B., Jebreil, M. N., \& Reza, Z. (2013). Yield evaluation and components of canola (Hyola 401) species in different densities of seed influence by Chemical, Farmyard manure and Vermicompost and Biological fertilizer. International Journal of Agriculture and Crop Sciences, 6(6), 305-312.

Biswas, J. C., Landha, J. K., \& Dazzo, F. B. (2000). Rhizobia inoculation improves nutrient uptake and growth of low land rice. Soil Science Society of American Journal, 64, 1644-1650. https://doi.org/10.2136/sssaj $2000.6451644 \mathrm{x}$

Burd, G. I., Dixon, D. G., \& Glick, B. R. (2000). Plant Growth Promoting Rhizobacteria that decreases heavy metal toxicity in plant. Canadian Journal of Microbiology, 33, 237-245. https://doi.org/10.1139/w99-143

Dehpouri, F., Abed, V., Esmaeil, Y., Omid, G., Chepi, \& Mohammad, H. H. (2015). Effects of phosphate solubilizing bacteria and mineral phosphorous levels on yield and yield components of canola Hyola 401 cultivar. Agricultural Advances, 4(1), 7-14.

Ebrahimi, C., Hossein, Esmaeil, Y., \& Hemmat, A. P. (2014). Effects of phosphate solubilizing bacteria and phosphorous levels on Rice (Oryza sativa L.). Agricultural Advances, 3(2), 56-66.

Fallik, E., \& Okon, Y. (1988). Growth response of maize roots to Azospirillum inoculation: Effect of soil organic matter content, number of rhizosphere bacteria and timing of inoculation. Soil Biochem., 20, 45-49. https://doi.org/10.1016/0038-0717(88)90125-3

Freitas, J. R., Banerjee, M. R., \& Germida, J. J. (1997). Phosphate solubilizing Rhizobacteria enhance the growth and yield but not Phosphorus uptake of Canola (Brassica napus L.). Biology and Fertility of Soil, 24(4), 358-364. https://doi.org/10.1007/s003740050258

Gleddie, S. C., Schlechte, D., \& Turnbull, G. (1993). Effect of inoculation with Penicillium Bilaji (provide) on phosphate and yield of canola in western Canada. Proc. Alberta Soil Science Workshop, Edmonton, Alberta, February 19-20, 1993 (pp. 155-160).

Gupta, P., \& Vishal, G. (2006). Studies on efficacy of Biofertilizers on yield of wheat (Triticum aestivum) and Mustard (Brassica juncea). Journal of Microbial World, 8(1), 51-56.

Khalid, A., Arshad, M., \& Zahir, Z. A. (2004). Screening plant growth-promotiong rhizobacteria for improving growth and yield of wheat. Journal of Applied Microbiology, 96(3), 473-480. https://doi.org/10.1046/ j.1365-2672.2003.02161.x

Lucy, M., Reed, E., \& Glick, B. R. (2004). Applications of free living plant growth-promoting rhizobacteria. Antonie Van Leeu Wen Hook, 86, 1-25. https://doi.org/10.1023/B:ANTO.0000024903.10757.6e

Marcos, A. K., \& Sutlle, J. C. (1995). Effects of compost on rhizosphere microflora of tomato and on the incidence of the plant growth promoting rhizobacteria. Canadian Journal of Microbiology, 61(1), 194-199.

Naveed, M., Zahir, Z. A., Khalid, M., Asghar, H. N., Akhtar, M. J., \& Arshad, M. (2008). Rhizobacteria containing ACC_deaminase for improving growth and yield wheat under fertilized condition. Pakistan Journal of Botany, 40(3), 1231-1241. 
Saber, Z., Hemmatollah, P., \& Ayub, H. (2013). Plant growth promoting rhizobacteria effects on yield and yield components of four rapeseed (Brassica napus L.) cultivars under salt condition. International Journal of Agriculture and Crop Sciences, 5(17), 1869-1873.

Sharma, S. K., Ram, M. R., \& Singh, D. P. (1997). Effects of crop geometry and nitrogen on quality and oil yield of Brassica species. Indian Journal of Agronomy, 42(2), 357-360.

Shukla, R. K., Kumar, A., Mahapatra, B. S., \& Kanpal, B. (2002). Integrated nutrient management practices in relation to morphological and physiological determination of seed yield in Indian mustard (Brassica juncea). Indian J of Agricultural Sciences, 72(11), 670-672.

Soleimanzadeh, H., \& Farshad, G. (2013). Response of growth and yield of maize to biofertilizer in organic and conventional cropping system. International Journal of Agriculture and Crop Sciences, 3(7), 797-801.

Sturz, A., \& Christie, B. (2003). Beneficial microbial allelopathies in the root zone: The management of soil quality and plant disease with rhizobacteria. Soil and Tillage Research, 72, 107-123. https://doi.org/ 10.1016/S0167-1987(03)00082-5

Tran, T. N. S., Cao, N. D., \& Truong, T. M. G. (2006). Effects of Brady Rhizobia and Phosphate Solublizing Bacteria application on soybean in rotational system in the Mekong delta. Omonrice, 14, 48-57.

Winarso, S., Didik, S., \& Eko, H. (2011). Effects of humic compounds and phosphate solubilizing bacteria on phosphorus availability in an acid soil. Journal of Ecology and the Natural Environment, 3(7), 232-240.

Yasari, E., Esmaeili Azadgoleh, A. M., \& Saedeh, M. (2008). Azotobacter and Azospirillium inoculation as biofertilizers in canola (Brassica napus L.) cultivation. Asian Journal of Plant Sciences, 7(5), 490-494. https://doi.org/10.3923/ajps.2008.490.494

Yasari, E., Esmaeili Azadgoleh, A. M., Pirdashti, H., Saedeh, M., \& Mahsa, R. A. (2009). Enhancement of growth and nutrient uptake of rapeseed (Brassica napus L.) by applying mineral nutrients and biofertilizers. Pakistan Journal of Biological Sciences, 12(2), 127-133. https://doi.org/10.3923/pjbs.2009.127.133

\section{Copyrights}

Copyright for this article is retained by the author(s), with first publication rights granted to the journal.

This is an open-access article distributed under the terms and conditions of the Creative Commons Attribution license (http://creativecommons.org/licenses/by/4.0/). 